\title{
Moderating Effect of Confidence in Solving Problem and English Achievement on the Performance of Fourth Year Students in Physics
}

\author{
Glen L. Villonez \\ F. Bangoy National High School, Davao City, Department of Education, Philippines \\ * Corresponding author email: glenvillonez.00@gmail.com
}

Received: 06 June 2018 / Revised: 01 September 2018 / Accepted: 23 September 2018 / Published: 02 October 2018

\begin{abstract}
The study aimed to determine the influence of problem-solving confidence and English achievement on the performance of fourth year students in physics. Specifically, it sought to find out whether English achievement significantly moderate the effect of problem-solving confidence on the performance in physics. Descriptive- predictive design was utilized in the study. The study was carried out in F. Bangoy National High School to sixty fourth year students. Mean and moderated regression were used as tools in the analysis of data. Results revealed that the level of problem-solving confidence in physics was moderate; the level of academic achievement in English was proficient and the level of performance of fourth year students in physics was also proficient. Further, English achievement significantly moderates the effect of problem-solving confidence on the performance of fourth year students in physics. Therefore, it was recommended to strengthen the connection of learning English and problem-solving ability through activities that encourage students to analyze and think critically in order to arrive at a correct solution.
\end{abstract}

Keywords: confidence, problem solving, english, performance, physics

\section{Introduction}

Physics as a discipline requires learners to employ a variety of methods of understanding and to translate from one to the other-words, tables of numbers, graphs, equations, diagrams, maps. Physics requires the ability to use algebra and geometry and to go from the specific to general and back. This makes learning Physics particularly difficult for many students (Ebora, 2016). Evidently, the 2012 National Achievement Test Mean Percentage Score of 48.90 which is far from the standard 75 percent indicated that students have performed poorly in science particularly in physics; and the lack of problem solving, and analytical skills were evidently considered as the reasons behind the subpar manifestation. To note, problem solving, and creativity are in the highest understanding active level of a human and it's counted as one of the most valued educational goals. In addition, student's self-confidence in performing a variety of academic tasks has an effect on their academic achievement (Njiru \& Karuku, 2015). Motlagh et al., (2011) affirmed that students who perform well in physics develop confidence in their physics capabilities translating to high grades in the subject.

In the study of Hedjazi et al., (2012) to agricultural majors' undergraduate students of University of Tehran, results revealed that there was positive and significant relationship between the creative and confidence styles of problem-solving and students' academic achievement. Moreover, it can be stated that the more agricultural students were confident and creative in solving problems, their academic achievement increases. Furthermore, the findings of Yin Yin and Kassim (2005) on economics students in Penang in 2004 revealed that students obtained higher scores in examinations questions were similar to their notes and work books. Also, students obtained better scores for lower thinking questions which were questions that tested knowledge, comprehension and simple application. On the contrary, for questions that were of higher thinking levels such as synthesis and evaluation, students faced great difficulties, hence; the findings showed that collaborative problem solving is helpful in training students to develop an independent learning style.

\section{Copyright (C) 2018. The Author(s). Published by AIJR Publisher.}

This is an open access article under Creative Commons Attribution-NonCommercial 4.0 International (CC BY-NC 4.0) license, which permits any non-commercial use, distribution, adaptation, and reproduction in any medium, as long as the original work is properly cited. 
Moderating Effect of Confidence in Solving Problem and English Achievement on the Performance of Fourth Year Students in Physics

Ultimately, this study aimed to determine the influence of problem-solving confidence and English achievement on the performance of fourth year students in physics. Specifically, it wanted to answer the subsequent queries:

1. What is the level of problem-solving confidence in physics of fourth year students of F. Bangoy National High School?

2. What is the level of academic achievement in English and Physics of fourth year students?

3. Do problem solving confidence and English achievement significantly influence performance of students in Physics? and

4. Does academic achievement in English significantly moderate the effect of problem-solving confidence on the performance of fourth year students in physics?

Furthermore, the following terms used in the study were defined operationally:

Problem solving confidence refers to the level of ability of the students to solve problems and measured in a 5- point Likert scale. Academic achievement refers to the performance of students in English. It is measured in terms of grade. Performance in physics refers to the academic achievement of students in physics and was measured also in terms of grade.

\section{Materials and Methods}

The study utilized descriptive- predictive research design which was concerned with and designed solely to explain the present distribution of variables, without regard to causal or other hypotheses. Meanwhile, it focused on predicting decisions about individuals or to aid in various types of selection. Correspondingly, simple random sampling design was employed where every individual in the population being sampled has an equal likelihood of being included. A total of sixty fourth year students of F. Bangoy National High School were selected as the respondents of the study. An adopted survey questionnaire with five-point Likert scale was used to gather responses from the respondents with regards to their problem-solving confidence. The questionnaire was originally developed by Tolga Gok. The questionnaire consisted of twenty- item questions. Moreover, the study made use of statistical tests for analysis of the data collated. These were the mean and moderated regression analysis. Mean was used to determine the level of problemsolving confidence, English achievement and students' performance in Physics; and moderated regression aimed to determine the influence whether academic achievement in English significantly moderate the effect of problem-solving confidence on the performance of students in Physics.

\section{Results and Discussion}

This section presents the analysis of the data collated and given a meaningful interpretation. Figure 1 highlighted the descriptive analysis of the variables.

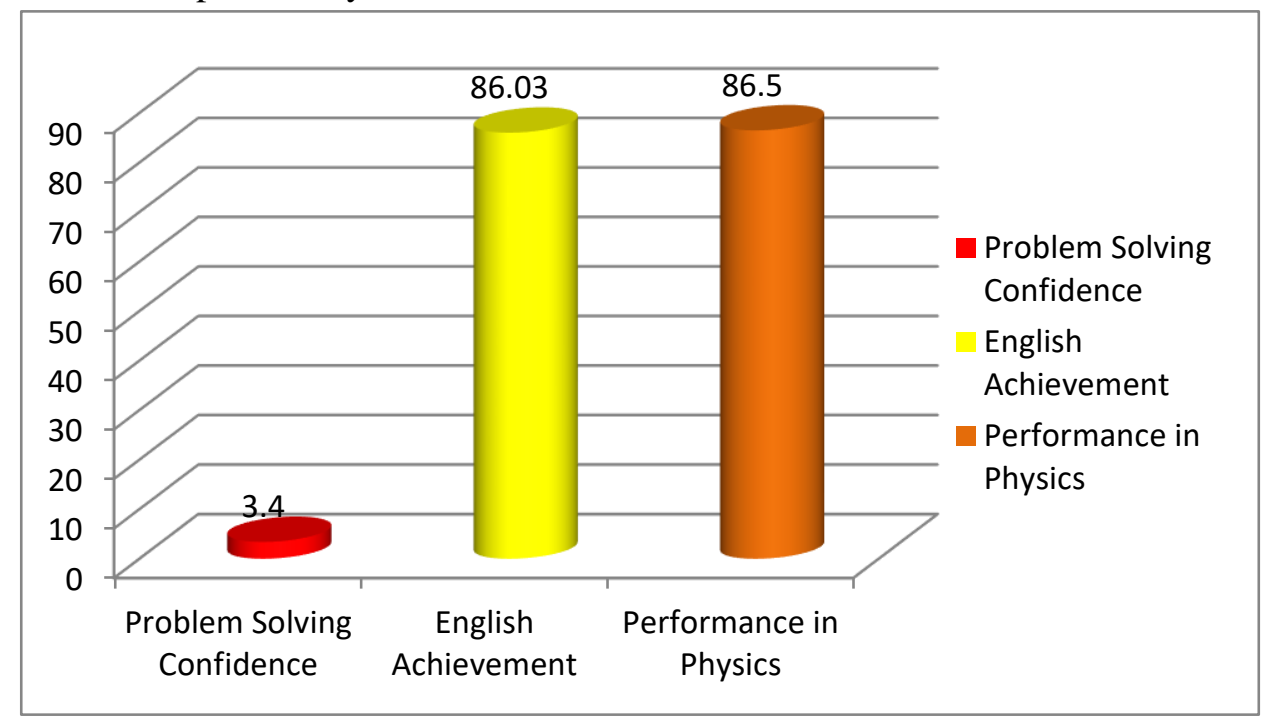

Figure 1: Descriptive Analysis of the Variables 
Glen L. Villonez., Adv. J Social Sci.; Vol. 4 Issue 1, pp: 24-27, 2019

In terms of problem-solving confidence, it reveals that problem-solving confidence obtained a mean rating of 3.40 which can be described as Moderate. This implies that fourth year students sometimes manifested problem-solving confidence in physics. Also, this means that students developed skills in solving problems in physics, hence, they showed confidence in solving problems. In addition, their exposures to drills and exercises made them engage to mathematical computations which entail analysis and problem solving.

For their English achievement, it garnered a mean rating of 86.03 which is described as proficient based on DepEd Order No. 73, s. 2012. This means that students have shown better performance in English. This is attributed to their exposure to learning strategies that are given in their English class. Also, the figure exemplified the level of performance in physics of fourth year students of F. Bangoy National High School which registered a mean rating of 86.50 which can be described as proficient. This means that students have demonstrated good performance in physics. This is attributed to strategies or approaches implemented by teacher in teaching the subject.

Table 1: Significance of Influence of the Moderating Effect of Problem-Solving Confidence and Academic Achievement in English on the Performance in Physics of Fourth Year Students of F. Bangoy NHS

\begin{tabular}{|c|c|c|c|c|c|c|c|}
\hline \multirow[b]{2}{*}{$\mathbf{R}^{2}$} & \multicolumn{2}{|c|}{$\begin{array}{l}\text { ANOVA } \\
\text { Summary }\end{array}$} & \multicolumn{5}{|c|}{ Regression } \\
\hline & $\mathbf{F}$ & $\begin{array}{l}\text { p- } \\
\text { value }\end{array}$ & & $\begin{array}{l}\text { Unstandar- } \\
\text { dized Beta }\end{array}$ & t-value & p-value & Remarks \\
\hline \multirow{4}{*}{.28} & \multirow{4}{*}{7.17} & \multirow{4}{*}{.000} & Constant & -236.94 & -1.77 & .082 & \\
\hline & & & Problem Solving Confidence & .28 & .17 & .862 & $\begin{array}{c}\text { Not } \\
\text { Significant }\end{array}$ \\
\hline & & & English Achievement & 3.75 & 2.07 & .043 & Significant \\
\hline & & & $\begin{array}{l}\text { Problem Solving Confidence X } \\
\text { English Achievement }\end{array}$ & -.92 & -2.45 & .017 & Significant \\
\hline
\end{tabular}

Table 1 flaunts the significance of influence of the moderating effect of problem-solving confidence and academic achievement in English on the performance in Physics of fourth year students of F. Bangoy NHS. Also, it shows that the product of problem-solving confidence and academic achievement in English obtained a p-value of .049 which is lesser than .05 in the level of significance significantly predict the performance in physics. Therefore, it implies that academic achievement in English significantly moderate the effect of problem-solving confidence on the performance of fourth year students in physics. In addition, academic achievement in English significantly predicts performance of students in physics.

The findings above agree with the idea of Carey (2004) which asserts that language skills are thought to develop number concepts to have an association to numerical skills even if this link is affected by difficulty of learning language and mathematics. Further, the connection between language skills and mathematics has been supported by early developmental theory (Gelman \& Butterworth, 2005).

\section{Conclusion}

From the findings of the study, it can be concluded that the level of problem-solving confidence in physics of fourth year students was moderate. Also, the level of academic achievement of fourth year students in English and Physics was proficient. Further, English achievement significantly predicts performance of students in physics. Moreover, academic achievement in English significantly moderates the effect of problem-solving confidence on the performance of fourth year students in physics. From these conclusions mentioned, it is therefore recommended to increase the problem-solving activities during physics time and to other areas in science for it might improve the confidence level of the students and increase the exposure of students to activities that might test their comprehension, analytical or critical thinking. 


\section{Declaration}

\subsection{Acknowledgment}

Special thanks to the Division Research Team of Davao City specifically to Dr. Elsie E. Gagabe, Dr. Wilson E. Gamao, Dr. Harlan Perasol, Dr. Arlenor Abelardo, Dr. Gerry Ferraren, Mack Arthur Gamayot, Larry Saliga, Eleser Mateo, Robert Quibete and Roland Baguio for their support and encouragement to finish this study.

\subsection{Study Limitation}

None

\subsection{Funding Source}

None

\subsection{Competing Interests}

None

\section{How to Cite this Article:}

Villonez, G. (2018). Moderating Effect of Confidence in Solving Problem and English Achievement on the Performance of Fourth Year Students in Physics. Advanced Journal of Social Science, 4(1), 24-27. Doi: 10.21467/ajss.4.1.24-27

\section{References}

Carey, S. (2004). Bootstrapping and the origin of concepts. Daedalus. 133 (1), 59-68. View

Ebora, A. (2016). Academic Performance in Physics of Fourth Year High School Students in one Public High School in Batangas City, Philippines. Asia Pacific Journal of Education, Arts and Sciences. 3 (3), 36-40.

Gelman, R., \& Butterworth, B. (2005). Number and language: How are they related? Trends in cognitive sciences. 9 (1), 6-10. View

Gok, T. (2012). Development of problem solving confidence questionnaire: study of validation and reliability. View

Hedjazi, S. Y., Shakiba, H., \& Monavvarifard, F. (2012). Effect of problem-solving styles on academic achievement of agricultural students in the University of Tehran. Scholars Research Library. View

Motlagh, S. E., Amrai, K., Yazdani, M. J., Abderahim, H. Altaib, \& Souri, H. (2011). The relationship between self-efficacy and academic achievement in high school students. Procedia - Social and Behavioral Sciences. 1 (15), 765-768.

Njiru, S. M., \& Karuku, S. (2015). An Exploration of Factors that Contribute to Low Performance in Physics: A Case of a Secondary School in Kenya. International Journal of Innovation and Scientific Research. 17 (2), 381-390.

Yin Yin, K., \& Kassim, Z. (2005). Pembelajaran Penyelesaian Masalah Secara Kaedah Kolaboratifdengan Pemikiran Kritisdan Kreatif di Kalangan Pelajar-pelajar Tingkatan Enam. Prosiding Seminar Pendidikan JPPG. 28-30.

Publish your research article in AIJR journals-

$\checkmark \quad$ Online Submission and Tracking

$\checkmark$ Peer-Reviewed

$\checkmark$ Rapid decision

$\checkmark \quad$ Immediate Publication after acceptance

$\checkmark \quad$ Articles freely available online

$\checkmark \quad$ Retain full copyright of your article.

Submit your article at journals.aijr.in
Publish your books with AIJR publisher-

$\checkmark \quad$ Publish with ISBN and DOI.

$\checkmark$ Publish Thesis/Dissertation as Monograph.

$\checkmark$ Publish Book Monograph.

$\checkmark$ Publish Edited Volume/ Book.

$\checkmark$ Publish Conference Proceedings

$\checkmark$ Retain full copyright of your books.

Submit your manuscript at books.aijr.org 